\title{
In Vitro Regulation of Cell Growth and Angiogenesis by Inositol Hexaphosphate in Bladder Cancer
}

\author{
Stanley J. Kandzari Dale Riggs Barbara Jackson \\ Adam Luchey Claire Oliver Stanley Zaslau
}

Section of Urology, Department Of Surgery, Robert C. Byrd Health Science Center, West Virginia University, Morgantown, W. Va., USA

\begin{abstract}
Key Words
Cellular anti-proliferation • Bladder cancer • Angiogenesis • Inositol hexaphosphate $\cdot$ Vascular endothelial growth factor
\end{abstract}

\begin{abstract}
Background: Inositol Hexaphosphate (IP6) is a naturally occurring polyphosphorylated carbohydrate that is found in food sources high in fiber content. We hypothesized that IP6 would inhibit the cell growth rate of bladder cancer in vitro. Methods: T24 and TCCSUP bladder cancer cell lines were treated with titrating doses of IP6 $(0.3,0.6$ and $0.9 \mathrm{mM} /$ well). Cell viability and vascular endothelial growth factor levels were measured. Results: Significant reductions $(p<0.001)$ in cellular growth were noted in both cell lines at all doses and time points tested, with the exception of $0.3 \mathrm{mM}$ IP6 at 24 hours in the T24 cell line. The percent inhibition of vascular endothelial growth factor was significantly higher than that observed in the TCCSUP cell line at 48 and 72 hours with 0.3 mM IP6 ( $p<0.001$ ). The T24 cells exhibited the same level of inhibition at 24 and 48 hours with $0.6 \mathrm{mM}$ dose of IP6 and at 72 hours with the $0.3 \mathrm{mM}$ dose $(p<0.001)$. Conclusions: In vitro treatment of bladder cancer with the common dietary polyphosphorylated carbohydrate IP6 significantly decreased cellular growth by anti-angiogenic mechanisms. We feel that this data warrants further investigation and consideration for initiation of clinical trials to evaluate the safety and clinical utility of this agent. Copyright $\odot 2012$ S. Karger AG, Basel
\end{abstract}

\section{KARGER}

Fax +4161306 1234

E-Mail karger@karger.ch

www.karger.com
(C) 2012 S. Karger AG, Basel

1015-9770/12/0064-0199\$38.00/0

Accessible online at:

www.karger.com/cur

\section{Introduction}

There will be 73,510 newly diagnosed cases of bladder cancer in 2012, with 55,600 being men and 17,910 being women. Approximately 1 in 5 of those who develop bladder cancer will die due to the disease (relative mortality 20.2\%) [1]. Bladder cancer has become the second most prevalent cancer after cancer of the prostate in middle-aged to elderly male individuals. Many patients do not die of their disease, but have multiple recurrences [2]. This lends to the fact that the 5-year cost to Medicare attributed to bladder cancer in the United States is over one billion dollars [3].

Carcinogen exposure is the leading cause of bladder cancer and cigarette smoking accounts for approximately $66 \%$ of the male and $30 \%$ of the female cancers with a 2 to 4-fold increase in risk when compared to non-smokers [4-7]. Leading presenting symptoms include hematuria (occurring up to 85\%) and irritative voiding symptoms such as dysuria and frequency [8]. Approximately 60$80 \%$ of newly diagnosed bladder cancers are superficial, either Ta, T1, or carcinoma in situ [9]. With local resection and no adjuvant intravesical therapy, progression rates for tumor grades I, II, and III and stage Ta and T1 to muscle-invasive cancer is 2,11 , and $45 \%$, respectively [10].

Intravesical chemotherapy with thiotepa [11], mitomycin C [12], or doxorubicin [13] had historically been the 
standard treatment for those patients suffering with bladder cancer. However, these chemotherapies have been unable to provide significant long-term benefit over that of transurethral resection alone [14]. Bacillus CalmetteGuerin (BCG) exhibits significant protection over that of surgical resection alone $[15,16]$ and has proven to be superior to that of chemotherapy with Doxorubicin in preventing tumor recurrence [17]. However, BCG is not without treatment related side effects and many patients will fail to respond to treatment. Therefore, alternative and potentially more effective and less toxic forms of therapy are needed.

Inositol hexaphosphate (IP6), a naturally occurring polyphosphorylated carbohydrate, is found in foods high in fiber content such as legumes and cereals [18], and is easily absorbed from the gastrointestinal tract making it safe in a regular diet. IP6 has been shown to inhibit both the in vivo and in vitro growth of numerous tumor and cell lines [19]. Present in most mammalian cells, IP6 plays an important role in regulating cell function, proliferation and differentiation [20]. The mechanisms by which IP6 exerts its anti-proliferative effects are through regulation of cell cycle, apoptosis and angiogenesis. Angiogenesis is the process in which new blood vessels are formed for tumor growth to occur [21]. One of the more common and specific methods used to detect angiogenic activity is through the measurement of vascular endothelial growth factor (VEGF) [22].

We hypothesized IP6 would inhibit the growth rate of bladder cancer in vitro and prove to be a potentially effective form of intravesical therapy for bladder cancer.

\section{Materials and Methods}

\section{Tissue Culture Media}

RPMI 1640 tissue culture media (Invitrogen, Grand Island, NY ) was employed for both cell passage and experimental procedures. RPMI was supplemented with $10 \%$ Fetal Bovine Serum (ATCC, Manassas, VA), 1\% Penicillin Streptomycin (Invitrogen, Grand Island, NY ) and 1\% Sodium Pyruvate (Sigma Chemical Company, St. Louis, MO).

\section{IP6}

IP6 (dodecasodium salt hydrate) derived from rice was purchased from Sigma Chemical Company (St. Louis, MO). IP6 was solubilized in RPMI 1640 tissue culture media (as described above) to the desired concentrations of $0.3,0.6$, and $0.9 \mathrm{mM} /$ well. After solubilization, the $\mathrm{pH}$ of IP6 was checked and determined to be 9.5 . The $\mathrm{pH}$ was then adjusted to a neutral $\mathrm{pH}$ of 7.0 using $1 \mathrm{~N}$ Hydrochloric acid, IP6 was then filtered using a 0.2 micron filter to assure sterility. Tissue culture media alone served as the control for all experimental procedures.

\section{Cell Culture and Reagents}

Two bladder cancer cell lines, TCCSUP (Grade IV), and T24 (Grade III) (ATCC, Manassas, VA) were maintained as monolayers in their preferred media (as described above) at $37^{\circ} \mathrm{C}$ in $5 \%$ $\mathrm{CO}_{2}$. Cell were trypsinized and then plated in sterile 96-well plates at $1 \times 10^{5}$ cells $/ \mathrm{ml}$. Cells were then returned to the incubator for 24 hours to allow adherence prior to exposure to IP6. Cells were treated with IP6 at the desired concentrations $0.3,0.6$ and $0.9 \mathrm{mM} /$ well and returned to the incubator for an additional 24,48 , and 72 hours. Prior to MTT assay, supernatants were collected and stored for later assay and quantification of VEGF levels ( $\mathrm{pg} / \mathrm{ml})$.

MTT Assay

The MTT colorimetric assay was performed to detect tumor cell viability after 24,48 and 72 hours of incubation. MTT, a tetrazolium dye (3-[4,5-dimethylthiazol-2-yl]-2,5-diphenyltetrazolium bromide; thiazolyl blue, Sigma chemical Co., St. Louis, MO) was added to each well as described previously [23]. Plates were incubated in the presence of MTT dye for 4 hours. Mitochondrial dehydrogenase activity reduced the yellow MTT dye to a purple formazan, which was then solubilized with acidified isopropanol and absorbance was read at $570 \mathrm{~nm}$.

\section{VEGF ELISA}

Human VEGF Quantikine ELISA Kit (R\&D Systems, Minneapolis, MN) was used to detect VEGF (pg/ml) after 24, 48 and 72 hours of incubation. Cell culture supernatants, standards, or control samples were added in $200 \mu$ increments to a precoated microplate containing a monoclonal antibody specific for VEGF. VEGF present in the samples will bind to the antibody. The microplate was then washed to release any unbound substances and an enzyme-linked polyclonal antibody specific for VEGF was added to each well. After incubation, a wash buffer was used to remove any unbound antibody-enzyme reagent and a substrate solution was added for color development. Once the color development was complete, the plate was read at $450 \mathrm{~nm}$.

\section{Statistical Analysis}

Determination of statistical significance was performed by analysis of variance (ANOVA) [24]. Post hoc comparison of individual concentration means with the control was completed using the Tukey-Kramer Multiple Comparison test [25]. All data are reported as means $\pm \mathrm{SD}$.

\section{Results}

\section{MTT Cell Viability Assay}

TCCSUP All doses of IP6 tested significantly reduced the proliferation of cells after 24 hours of exposure (table 1). An $11.7 \pm 7.0 \%$ reduction in proliferation was observed with $0.3 \mathrm{mM}$ IP6 $(\mathrm{p}=0.004)$, followed by $73.8 \pm$ $6.4 \%$ with $0.6 \mathrm{mM}$ IP6 $(\mathrm{p}<0.001)$ and $82.3 \pm 3.6 \%$ with 0.9 mM IP6 ( $p<0.001)$. After 48 hours, 0.9 mM IP6 exhibited the greatest degree of anti-proliferation with a reduction in cell growth of $91.5 \pm 1.0 \%(\mathrm{p}<0.001)$, closely followed by $0.6 \mathrm{mM}(85.4 \pm 2.6 \%, \mathrm{p}<0.001)$. A $32.2 \pm$ 
Table 1. TCCSUP cell line: evaluation of the dose and time dependent in vitro anti-proliferative effects of IP6 as measured by MTT assay

\begin{tabular}{|c|c|c|c|c|}
\hline Incubation time & Mean growth inhibition, $\%$ & Number & SD & $\mathrm{p}$ (vs. control) \\
\hline \multicolumn{5}{|l|}{24 hours } \\
\hline Control & 0 & 6 & 0.1 & \\
\hline $0.3 \mathrm{mM}$ IP6 & 11.7 & 6 & 7.0 & 0.004 \\
\hline $0.6 \mathrm{mM}$ IP6 & 73.8 & 6 & 6.4 & 0.001 \\
\hline $0.9 \mathrm{mM}$ IP6 & 82.3 & 6 & 3.6 & $<0.001$ \\
\hline 48 hours & & & ANOVA & $<0.001$ \\
\hline Control & 0 & 6 & 0.1 & \\
\hline $0.3 \mathrm{mM}$ IP6 & 32.2 & 6 & 4.4 & $<0.001$ \\
\hline $0.6 \mathrm{mM}$ IP6 & 85.4 & 6 & 2.6 & $<0.001$ \\
\hline 0.9 mM IP6 & 91.5 & 6 & 1.0 & $<0.001$ \\
\hline 72 hours & & & ANOVA & $<0.001$ \\
\hline Control & 0 & 6 & 0.1 & \\
\hline $0.3 \mathrm{mM}$ IP6 & 26.2 & 6 & 4.6 & $<0.001$ \\
\hline 0.6 mM IP6 & 92.3 & 6 & 0.6 & $<0.001$ \\
\hline \multirow{2}{*}{0.9 mM IP6 } & 92.9 & 6 & 0.8 & $<0.001$ \\
\hline & & & ANOVA & $<0.001$ \\
\hline
\end{tabular}

Table 2. T24 cell line: evaluation of the dose and time dependent in vitro anti-proliferative effects of IP6 as measured by MTT assay

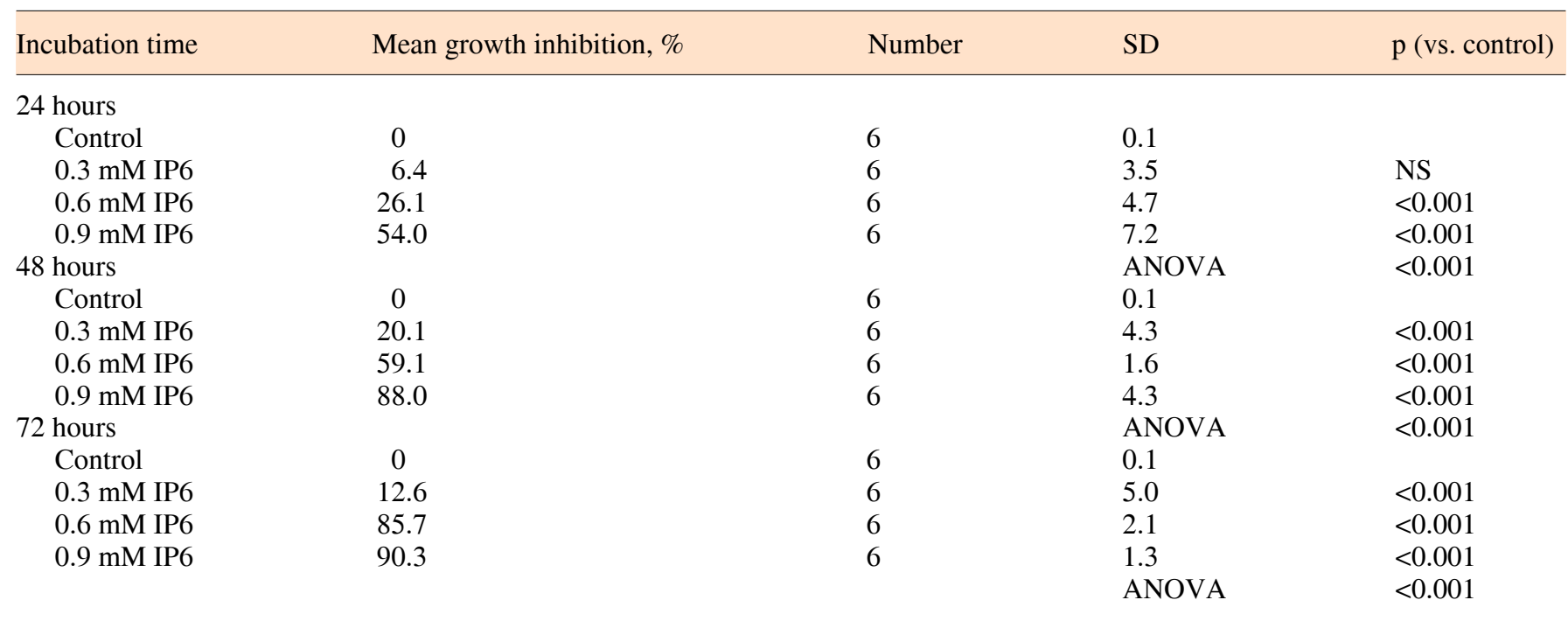

NS = Not significant.

$4.4 \%$ reduction was seen with $0.3 \mathrm{mM}$ IP6 $(\mathrm{p}<0.001)$. After 72 hours, $0.9 \mathrm{mM}$ IP6 $(92.9 \pm 0.8 \%, \mathrm{p}<0.001)$ and 0.6 mM IP6 $(92.3 \pm 0.6 \%, \mathrm{p}<0.001)$ exhibited nearly equivalent anti-proliferative effects in the TCCSUP cell line (table 1), while a $26.2 \pm 4.6 \%(\mathrm{p}<0.001)$ reduction was observed with $0.3 \mathrm{mM}$ IP6.

T24 Both 0.6 mM IP6 $(26.1 \pm 4.7 \%)$ and $0.9 \mathrm{mM}$ IP6 $(54.0 \pm 7.2 \%)$ significantly inhibited cellular prolifera- tion after 24 hours of incubation (table $2, \mathrm{p}<0.001$ ). After 48 hours, all 3 IP6 doses tested exhibited significant reductions in cellular proliferation (table 2). The greatest reduction in cellular proliferation was observed with 0.9 $\mathrm{mM}$ IP6 $(88.0 \pm 4.3 \%, \mathrm{p}<0.001)$, followed by $0.6 \mathrm{mM}$ IP6 $(59.1 \pm 1.6 \%, \mathrm{p}<0.001)$, and $0.3 \mathrm{mM}$ IP6 $(20.1 \pm$ $4.3 \%, \mathrm{p}<0.001)$. As was observed at 48 hours, all 3 doses of IP6 exhibited significant reductions in cell prolif- 


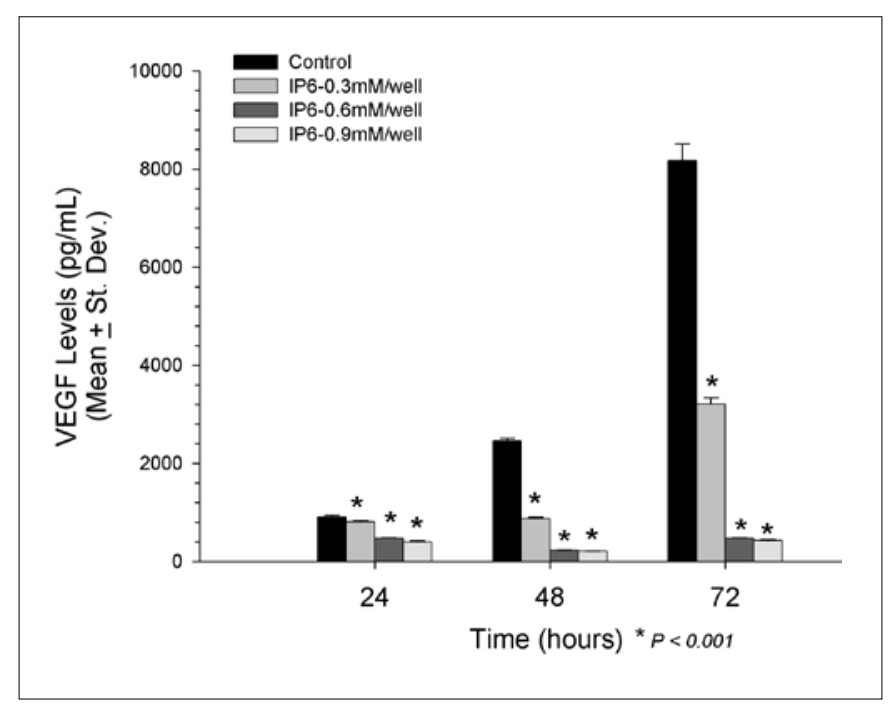

Fig. 1. Significant reduction in VEGF was observed in all 3 IP6 doses tested and all time points assayed in TCCSUP cell line.

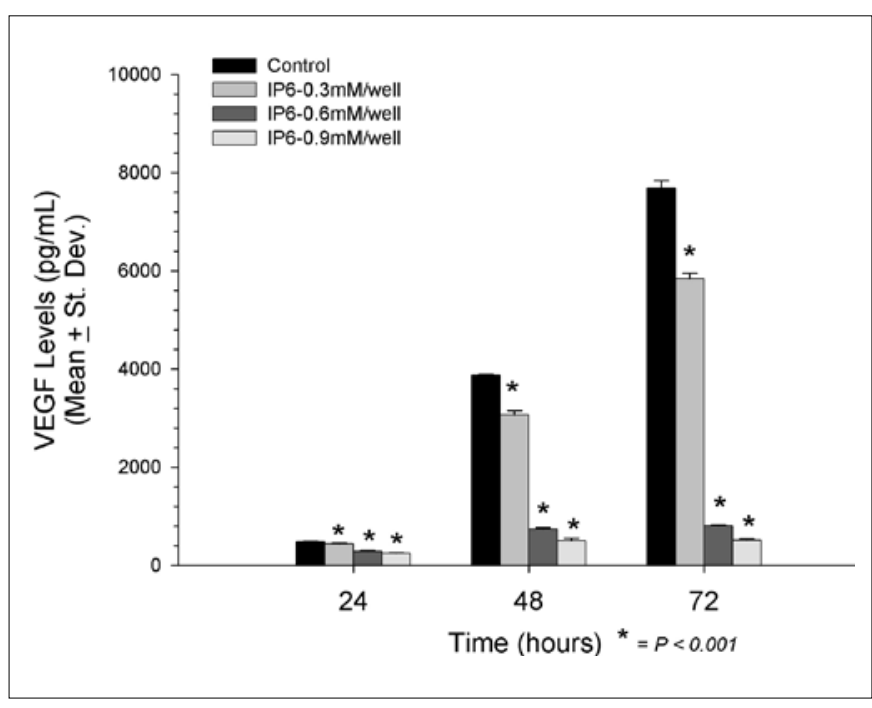

Fig. 2. VEGF changes in all 3 IP6 doses tested and all time points assayed in T24 cell line.

reductions in VEGF were noted in the TCCSUP cells.

T24 After 24 hours, VEGF levels were significantly reduced in all doses of IP6 used (fig. 2). The greatest reduction in VEGF was observed by 0.9 mM IP6 (247.8 \pm $12.2 \mathrm{pg} / \mathrm{ml}, \mathrm{p}<0.001)$ compared to control $(481.2 \pm 16.2$ $\mathrm{pg} / \mathrm{ml})$, followed by $0.6 \mathrm{mM} \mathrm{IP6}(287.1 \pm 16.3 \mathrm{pg} / \mathrm{ml}, \mathrm{p}<$ $0.001)$ and $0.3 \mathrm{mM}$ IP6 (435.4 $\pm 22.2 \mathrm{pg} / \mathrm{ml}, \mathrm{p}<0.001)$. The dose-dependent reduction in VEGF production continued after 48 hours with $0.9 \mathrm{mM}$ IP6 showing the greatest inhibitory effect $(507.1 \pm 45.6 \mathrm{pg} / \mathrm{ml}, \mathrm{p}<0.001)$, followed by $0.6 \mathrm{mM}$ IP6 $(738.6 \pm 31.2 \mathrm{pg} / \mathrm{ml}, \mathrm{p}<0.001)$ and $0.3 \mathrm{mM}$ IP6 $(3065.7 \pm 88.2 \mathrm{pg} / \mathrm{ml}, \mathrm{p}<0.001)$. The control group yielded a VEGF level of $3875.6 \pm 13.0 \mathrm{pg} /$ $\mathrm{ml}$ after 48 hours. The protective effects of IP6 in regards to VEGF production continued at 72 hours, with $0.9 \mathrm{mM}$ IP6 exhibiting the most dramatic reduction in VEGF levels $(514.5 \pm 24.7 \mathrm{pg} / \mathrm{ml}, \mathrm{p}<0.001)$, again followed by $0.6 \mathrm{mM}$ IP6 $(805.5 \pm 23.8 \mathrm{pg} / \mathrm{ml}, \mathrm{p}<0.001)$, and $0.3 \mathrm{mM}$ IP6 $(5834.4 \pm 120.5 \mathrm{pg} / \mathrm{ml}, \mathrm{p}<0.001)$. All three of these levels were significantly reduced when compared to the control groups at 72 hours $(7681.5 \pm 152.4 \mathrm{pg} / \mathrm{ml})$.

\section{Discussion}

Although many patients will respond well to conventional intravesical therapies, a significant number will experience tumor recurrence and/or treatment limiting toxicities. Intravesical therapy with BCG gained popularity 
in the 1980's based on reports by Morales et al. [15] and Lamm et al. [16] showing that BCG provided significant protection from tumor recurrence, progression and mortality. A Southwest Oncology Group study randomized 262 eligible patients to receive either chemotherapy with Doxorubicin or immunotherapy with BCG. BCG was shown to provide significantly better protection from tumor recurrence with $70 \%$ of those patients receiving BCG achieving a complete response compared to $34 \%$ in the doxorubicin arm $(\mathrm{p}<0.001)$ [17]. Although the use of intravesical immunotherapy with BCG has been shown to be the most effective form of treatment to date for those patients with bladder cancer, it is not without treatment related toxicity and many patients will fail to respond to initial treatment. Therefore, alternative and potentially more effective and less toxic forms of therapy are needed.

IP6 is a naturally occurring carbohydrate that is found in most cereals, grains, legumes, seeds and other foods that are high in fiber such as wheat bran and flaxseed [26]. Anti-proliferative effects of IP6 have been expressed in various tumors such as breast [27, 28], colon [29], liver [30], prostate [31-33], pancreas [34], melanoma [35] and Barrett's adenocarcinoma [36]. The effects of IP6 have been reported to be cancer cell specific and not cytotoxic nor cytostatic against normal cells. When leukemic progenitor cells were treated with IP6, there was no reported effect on normal progenitor CD34+ cells derived from bone marrow [37].

In our current study, the in vitro growth of T24 and TCCSUP bladder cancer cell lines treated with titrating doses of IP6 (0.3, 0.6 and $0.9 \mathrm{mM} /$ well) was significantly reduced. Cell viability was measured by MTT after 24, 48 and 72 hours. Significant reductions $(p<0.001)$ in cellular growth were noted in both cell lines at all doses and time points tested, with the exception of $0.3 \mathrm{mM} /$ well IP6 at 24 hours in the T24 cell line.

Regulating cell cycle, apoptosis and angiogenesis are among the reported mechanisms by which IP6 exerts its anti-proliferative effects. Through angiogenesis, tumor cells leave the primary site and enter the blood stream where new blood vessels form and tumor cells metastasize. The most common tumor angiogenic factors are the fibroblast growth factor and theVEGF [22, 38]. As cells undergo angiogenesis, both fibroblast growth factor and VEGF levels increase during the proliferative process. A reduction in these levels as a direct result of treatment, as in this case IP6, indicates that agent is acting as a modulator of angiogenesis [22].
Vucenik et al. [22] reported inhibitory effects of IP6 on angiogenic activity in the HepG2 cells. These researchers pretreated HepG2 cells with $0.5,1.0$ and 2.0 mM IP6 for 24 hours. At specific time points, aliquots of cell supernatants were removed to determine VEGF protein levels as measured by ELISA. These results showed that IP6 reduced VEGF levels by about $50 \%$ in a concentration-dependent manner. The HepG2 cells were recultured in serum-free media in the absence of IP6 for an additional 24 hours. A continued reduction in VEGF levels was observed by $79 \%$ with $1.0 \mathrm{mM}$ IP6 and $86 \%$ with $2.0 \mathrm{mM}$ IP6.

Our laboratory has previously reported that IP6 inhibited VEGF levels in two human pancreatic cancer cell lines [34]. The results showed that VEGF levels were significantly reduced to $343 \pm 23 \mathrm{pg} / \mathrm{ml}$ when compared to control $(1084 \pm 44 \mathrm{pg} / \mathrm{ml})$ in the MIA PaCa- 2 cells and decreased from control of $1465 \pm 319$ to $936 \pm 35 \mathrm{pg} / \mathrm{ml}$ with $0.8 \mathrm{mM} /$ well IP6 in the PANC-1 cells.

In the present study, VEGF (pg/ml) was significantly reduced $(\mathrm{p}<0.001)$ in both cell lines at all time points and doses tested. However, to determine if the reduction of VEGF was due to the relative decrease in cell growth as observed by the MTT assay, VEGF levels (pg/ml) were converted to percent $(\%)$ change versus control. The percent inhibition of VEGF was significantly higher than that observed by MTT $(p<0.001)$ in the TCCSUP cell line at both 48 and 72 hours with $0.3 \mathrm{mM}$ IP6. T24 cells exhibited the same level of inhibition at 24 and 48 hours with $0.6 \mathrm{mM} /$ well dose of IP6 and at 72 hours with the $0.3 \mathrm{mM} /$ well dose $(\mathrm{p}<0.001)$. The observed reductions in VEGF production would indicate that IP6 reduces cellular proliferation and growth at least in part by anti-angiogenic mechanisms.

\section{Conclusion}

IP6 has demonstrated significant and reproducible reductions in the growth of bladder cancer in vitro. The significant reductions in VEGF would suggest that IP6 reduces cellular growth at least in part by anti-angiogenic mechanisms. The results presented herein warrants further investigation, both in vitro and in vivo, leading to the initiation of Phase II clinical trials to evaluate the safety and clinical utility of this agent. 


\section{References}

-1 Siegel R, Naishadham D, Jemal A: Cancer Statistics, 2012. CA Cancer J Clin 2012;62: 10-29.

2 Pelucchi C, Bosetti C, Negri E, Malvezzi M, La Vecchia C: Mechanisms of disease: the epidemiology of bladder cancer. Nat Clin Pract Urol 2006;3:327-340.

-3 Yabroff K, Lamont E, Mariotto A, Warren JL, Topor M, Meekins A, Brown ML: Cost of care for elderly cancer patients in the United States. J Natl Cancer Inst 2008;100:630641.

4 Brennan P, Bogillot O, Cordier S, Greiser E, Schill W, Vineis P, Lopez-Abente G, Tzonou A, Chang-Claude J, Bolm-Audorff U, Jöckel $\mathrm{KH}$, Donato F, Serra C, Wahrendorf J, Hours M, T'Mannetje A, Kogevinas M, Boffetta P: Cigarette smoking and bladder cancer in men: a pooled analysis of 11 case-control studies. Int J Cancer 2000;86:289-294.

$>5$ Brennan P, Bogillot O, Greiser E, ChangClaude J, Wahrendorf J, Cordier S, Jöckel KH, Lopez-Abente G, Tzonou A, Vineis P, Donato F, Hours M, Serra C, Bolm-Audorff U, Schill W, Kogevinas M, Boffetta P: The contribution of cigarette smoking to bladder cancer in women (pooled European data). Cancer Causes Control 2001;12:411-417.

6 6 Burch JD, Rohan TE, Howe GR, Risch HA, Hill GB, Steele R, Miller AB: Risk of bladder cancer by source and type of tobacco exposure: a case-control study. Int J Cancer 1989; 44:622-628.

7 Baris D, Karagas MR, Verrill C, Johnson A, Andrew AS, Marsit CJ, Schwenn M, Colt JS, Cherala S, Samanic C, Waddell R, Cantor KP, Schned A, Rothman N, Lubin J, Fraumeni JF Jr, Hoover RN, Kelsey KT, Silverman DT: A case-control study of smoking and bladder cancer risk: emergent patterns over time. J Natl Cancer Inst 2009;101:1553-1561.

$>8$ Wakui M, Shiigai T: Urinary tract cancer screening through analysis of urinary red blood cell volume distribution. Int $\mathbf{J}$ Urol 2000;7:248-253.

$\checkmark 9$ Shelley MD, Mason MD, Kynaston H: Intravesical therapy for superficial bladder cancer: a systematic review of randomised trials and meta-analyses. Cancer Treat Rev 2010;36: 195-205.

10 Heney NM, Ahmed S, Flanagan MJ, Frable W, Corder MP, Hafermann MD, Hawkins IR: Superficial bladder cancer: progression and recurrence. J Urol 1983;130:1083-1086.

11 Byar D, Blackard C: Comparisons of placebo, pyridoxine and topical thiotepa in preventing recurrence of stage I bladder cancer. Urology 1977;10:556-561.

12 Huland H, Otto U: Mitomycin instillation to prevent recurrence of superficial bladder carcinoma. Results of a controlled, prospective study in 58 Patients. Eur Urol 1983;9:84-86.
3 Niijima T, Koiso K, Akaza H: Randomized clinical trial on chemoprophylaxis of recurrence in cases of superficial bladder cancer. Cancer Chemother Pharmacol 1983;11 Suppl:S79-82.

14 Lamm DL, Riggs DR, Traynelis CL, Nseyo UO: Apparent failure of current intravesical chemotherapy prophylaxis to influence the long-term course of superficial transitional cell carcinoma of the bladder. J Urol 1995; 153:1444-1450.

15 Morales A, Eidinger D, Bruce AW: Intracavity Bacillus Calmette-Guerin in the treatment of superficial bladder tumors. J Urol 1976; 116:180-183

16 Lamm DL, Thor DE, Harris SC, Reyna JA, Stogdill VD, Radwin HM: Bacillus CalmetteGuerin immunotherapy of superficial bladder cancer. J Urol 1980;124:38-40.

17 Lamm DL, Blumenstein BA, Crawford ED, Montie JE, Scardino P, Grossman HB, Stanisic TH, Smith JA Jr, Sullivan J, Sarosdy MF: A randomized trial of intravesical doxorubicin and immunotherapy with bacille Calmette-Guérin for transitional-cell carcinoma of the bladder. N Engl J Med 1991; 325:1205-1209.

18 Fox CH, Eberl M: Phytic acid (IP6), novel broad spectrum anti-neoplastic agent: a systematic review. Complement Ther Med 2002; 10:229-234.

19 Vucenik I, Shamsuddin AM: Cancer inhibition by inositol hexaphosphate (IP6) and inositol: from laboratory to clinic. J Nutr 2003; 133(11 Suppl 1):3778S-3784S.

20 Vucenik I, Shamsuddin AM: Protection against cancer by dietary IP6 and inositol. Nutr Cancer 2006;55:109-125.

21 Hicklin DJ, Ellis LM: Role of the vascular endothelial growth factor pathway in tumor growth and angiogenesis. J Clin Oncol 2005; 23:1011-1027.

22 Vucenik I, Passaniti A, Vitolo MI, Tantivejkul K, Eggleton P, Shamsuddin AM: Antiangiogenic activity of inositol hexaphosphate (IP6). Carcinogenesis 2004;25:2115-2123.

23 Mosmann T: Rapid colorimetric assay for cellular growth and survival: application to proliferation and cytotoxicity assays. J Immunol Methods 1983;65:55-63.

24 Ludbrook J: Multiple comparison procedures updated. Clin Exp Pharmacol Physiol 1998; 25:1032-1037.

25 Dixon WJ, Massey FJ: Introduction to statistical analysis, ed 4. New York, McGraw-Hill, 1983.

-26 Matejuk A, Shamsuddin A: IP6 in cancer therapy: past, present and future. Curr Cancer Ther Rev 2010;6:1-12.
27 Shamsuddin AM, Yang GY, Vucenik I: Novel anti-cancer functions of IP6: growth inhibition and differentiation of human mammary cancer cell lines in vitro. Anticancer Res 1996;16:3287-3292.

28 Shamsuddin AM, Vucenik I: Mammary tumor inhibition by IP6: a review. Anticancer Res 1999;19:3671-3674.

29 Jenab M, Thompson LU: Phytic acid in wheat bran affects colon morphology, cell differentiation and apoptosis. Carcinogenesis 2000; 21:1547-1552.

30 Vucenik I, Zhang ZS, Shamsuddin AM: IP6 treatment of liver cancer. II. Intra-tumoral injection of IP6 regresses pre-existing human liver cancer xenotransplanted in nude mice. Anticancer Res 1998;18:4091-4096.

-31 Shamsuddin AM, Yang GY: Inositol hexaphosphate inhibits growth and induces differentiation of PC-3 human prostate cancer cells. Carcinogenesis 1995;16:1975-1979.

32 Singh RP, Agarwal C, Agarwal R: Inositol hexaphosphate inhibits growth, and induces G1 arrest and apoptotic death of prostate carcinoma DU145 cells: modulation of CDKI$\mathrm{CDK}$-cyclin and $\mathrm{pRb}$-related protein-E2F complexes. Carcinogenesis 2003;24:555563

-33 Agarwal C, Dhanalakshmi S, Singh RP, Agarwal R: Inositol hexaphosphate inhibits growth and induces G1 arrest and apoptotic death of androgen-dependent human prostate carcinoma LNCaP cells. Neoplasia 2004;6: 646-659.

-34 McMillan B, Riggs DR, Jackson BJ, Cunningham $C$, McFadden DW: Dietary influence on pancreatic cancer growth by catechin and inositol hexaphosphate. J Surg Res 2007; 141:115-119.

35 Rizvi I, Riggs DR, Jackson BJ, Ng A, Cunningham $\mathrm{C}, \mathrm{McF}$ adden DW: Inositol hexaphosphate (IP6) inhibits cellular proliferation in melanoma. J Surg Res 2006;133:3-6.

- 36 McFadden DW, Riggs DR, Jackson BJ, Cunningham C: Corn-derived carbohydrate inositol hexaphosphate inhibits Barrett's adenocarcinoma growth by pro-apoptotic mechanisms. Oncol Rep 2008;19:563-566.

- 37 Deliliers GL, Servida F, Fracchiolla NS, Ricci C, Borsotti C, Colombo G, Soligo D: Effect of inositol hexaphosphate (IP(6)) on human normal and leukaemic haematopoietic cells. Br J Haematol 2002;117:577-587.

38 Zetter BR: Angiogenesis and tumor metastasis. Annu Rev Med 1998;49:407-424. 